\title{
Students Characters' Development through Mathematics on the subjects of Decimal and Block
}

\author{
Orin Asdarina \\ \{orin.asdarina@gmail.com\} \\ Department of Mathematics Education, STKIP Muhammadiyah, Aceh Barat Daya
}

\begin{abstract}
The purpose of this research is to find the development of students' characters' through the uses of mathematics on the subjects of decimals and blocks in MIN Tungkop, Aceh Besar, specifically on the class V2. The subjects of this research are 9 students chosen out of 36 , consist of 3 male students and 6 female students. The research data is collected through observation and interviews with the students. The data is analyzed using qualitative method based on the indicators of the observed characteristics. According to research, it is known that students characters' did developed on the characters of democratic, independent, curiosity, creative thinking and critical thinking.
\end{abstract}

Keywords: Characters, students, decimals, blocks

\section{Introduction}

These days, our nation is very concerned in discussing the topics of morality of students behavior, in which it is quite concerning. The action of teenagers are smeared with acts like cheating on a test, bullying and brawling with each other's. These actions did not reflects their status as a students who are educated, cultured, and morally good. These actions caused severe damage and could not be taken lightly as it is already bordering into a criminal acts.

The rampant increase of moral crises raises the concern of many elements of the nation, which formed an effort to find the solution to abolish these moral crises. One such effort is through the medium of education. A government effort in improving the education system have been done which are by developing a characters education system. The government has implanted a curriculum with characters in mind. As stated in ministerial regulation of education and culture of Indonesian Republic (PERMENDIKBUD-RI) in accordance to the 2013 curriculum stated that the curriculum prioritize the balance between soft skills and hard skills which include the aspects of attitude competence (affective), skill (psychomotor), and knowledge (cognitive).

Regarding the results of a Harvard University research (Sudarjat, 2010) which stated that the success was determined by $20 \%$ of knowledge and technical abilities (hard skill), while the other $80 \%$ soft skill. These signaled that the quality of character education is very important and needs to be improved and expanded. 
Ki Hadjar Dewantara in Zubaedi, 2013, stated that "character can be molded through education, because education is the most effective tool to build up the humanity inside an individual". In the future, a more capable generation would be provided with positive customs.

Character development on students is not easy, it takes sustainable efforts to be a success. For that reasons, it needed to be supported by character educations in schools.

[1] stated that "character education in school could be implemented through the learning process and have to be integrated in all school subjects, including mathematics". In a math lesson, student's characters could be developed in many ways, one of which is by encouraging the students to be consistent in thinking, consistent in using terms, and consistent in calculations. Then, it could also be done by improving students discipline and to always respect other people opinion. This is also in accordance to the characters of math which is to encouraging students to think more critically, more logically, and more creative. The intended characters for the students that teachers wants to develop includes characteristics like democratic, independent, curiosity, creative and critical in learning math.

Mathematics lesson is a way to make students learn math. Students' character development by using mathematics is best done as soon as possible. In this context, it's mathematics lesson on a grade school level. According to [2] early character development is very important to mold their adult character, internalizing the character strongly inside the individual, not restricted by their knowledge and understanding.

According to previous study results that the researcher had done with an elementary school teacher in Banda Aceh who stated that student's character development through math lessons at elementary school is rarely done, this is in correspondence to [3] research that stated that character development through math should be done as soon as possible but is still rarely done in primary school. There are many problems encountered on primary level mathematics. One of which is the lack of interest by the students when learning mathematics, some students even admitted to have phobia of math and feels burdened by it. On top of that, the teacher's method in teaching mathematics method is not suitable, the teacher method uses by the teacher sometimes make the in-class lessons less effective in developing.

This paper presents the results of the research on student's character development through mathematics lesson.

\subsection{Student's Character Development}

Elementary student's character development cannot be separated from the role of curriculum. In 2013 curriculum, integrated thematic learning are applied in every class at elementary school level. Integrated thematic learning is a teaching approach that integrated many competence from many subjects into multiple themes as the unifier where the delivery model connects each subjects into each other. Furthermore, a selection of sub-themes by paying attention to their correlation to the subjects. In 2013 curriculum there are 5 main learning experience which are more known as scientific approach (observing, asking, gathering information, associating, communicating). Through this scientific approach, 2013 curriculum could be implemented in mathematic lesson in developing student's character.

According to Musfiroh [4],"character refers to a series of attitude, behavior, motivation and skill". Scerenco (1997) define character as attribute or features that form and differentiate personality, ethics, and mental complexity of an individual, group or a nation. As an identity of a nation, character is the base behavior value as the point of reference for interaction value between human.Character could mean as a mixture of unique individual characteristic in thinking, behave and act in life, socializing, working in team or in solving problems in their environment. Those characters is connected to the psychological aspect (emotion, personality, 
character, attitude, nature, temperament or temperament), moral aspect (acknowledged and believed value), and cognitive aspect (style of thinking, reasoning, and uses of language). Thereby, the real character did not only contain values, but also capabilities, conviction, morality, emphatic capabilities, as well as the realization of the character.

\subsection{Good Character}

Philosophically, Aristoteles define that a good character is a life lived with good nature, in this context, it consist of the policy of self-oriented wisdom like self-control, simplicity and community oriented virtue like generosity and politeness [5]

[6] stated that "the habit of doing good does not always guarantee that the man who had been accustomed to consciously appreciate the importance of the value of the character". According to this definition, it could be concluded that good habits did not always guarantee that the individual is accustomed to consciously respects the value of a character. Because of that, character comprise of three things which is knowing the good, feeling the good and acting the good. The concept of a 'good' character is understand as good values. The character itself consists of a number of values that could be known, felt and acted upon.

The research and development agency of the Ministry of National Education Curriculum Center (Pusat Kurikulum Kementrian Pendidikan Nasional) (2011:10) has formulate the subjects of character education that consist of the following asepcts; Religious, Honest, Tolerant, Discipline, Hard Working, Creative, Independent, Democratic, Curiosity, Nationalist, Patriotism, Acknowledging Achievement, Communicative, Peaceful, Like to Read, Socially Aware and Responsible.

In this particular research, the researcher only observe three development of a good character which is; Democratic, Independent and Curiosity.

According to [7] a democratic character is a way of thinking, act and behave that value right and responsibilities of themselves as the same as others. While independent is the attitude and behavior that is not dependant on others in performing an action. Curiosity meanwhile is an attitude or behavior that always put in effort to dig deeper and widen their knowledge of something that they studied, seen or heard.

\subsection{Smart Character}

[8] stated that "Intelligence is the ability to solve problems; or to create products, that are valued within one or more cultural".

Praytino and Afriva (2009) reveals the value of a smart character; Active/dynamic, focused/logical, analytic and objective, able to solve problems/finding solution, creative, forward thinking, consistent, open and positive minded. In this research, the researcher would only developed two smart characters which are; creative and critical thinking.

According to [9] creativity is a product of an individual creative thinking. Thinking creatively is a process done when concocting a new idea. This is done by combining previous idea that has not been realized. This would be useful in finding the solution for it.

The capabilities of an individual creative thinking is shown through the products of the mind or the creativity in producing something new. According to Munadar (1999:50) creative thinking is an ability that reflects the fluency, flexibility and originality in thinking, as well as the ability to elaborate (develop, enrich and detailed) a suggestion. Then according to [10]"A special aspects of creative thinking is to think divergent, and has characteristics of flexibility, originality, and fluency (flexibility, originality and output quantity)".

The other smart character developed in this research is critical thinking. According to Ennis (1993), critical thinking a rational reflective thinking focused on deciding what to 
believe or do. [11] stated that critical thinking is a cognitive ability to state something with full conviction based on a logical reasoning and strong evidence.

Critical thinking skills related to the ability to identify, analyze and solve problems with the result in the considerations to obtain the right decision. Indicators of critical thinking skills by Ennis (1991) there are six elements of critical thinking skills that must be developed in learning, especially learning of math. The sixth element by Ennis abbreviated as FRISCO consisting of:

a. Focus on the subject matter

b. The reason given logical and in accordance with the focus of the problem

c. Inference: able to make conclusions with the right reasons.

d. Situation: match with the actual situation

e. Clarity: the existence of clarity regarding the term used so that no one in reaching Conclusions

f. Overview: check the back of the already decided

\section{$2 \quad$ Research Method}

This research uses descriptive method. The research location is Madrasah Ibtidaiyah Negeri (MIN) Tungkop, Aceh Besar Regency. This school is one of partner school of P4MRI University of Syiah Kuala that has integrated character education in both learning process and school culture. This research is done in four class of decimal subjects and extended into three class on block subjects.

The subject of this research is 36 students of class V-2, consists of 29 female students and 7 male students. From the 36 students, 9 were observed to determine the character, consists of 6 female students and 3 male students, therefore observing 3 students at a time. During the research, every students that being observed are the same students. The observed students are picked randomly based on the researcher discussion with the homeroom teacher of the class. To observe the character development.

In order to collect credible data, other than using observation sheets, research also record all learning activity using a handy cam, taking photos, and collecting student's works. The resulting video was then made into transcript and redacted, then grouped based on observed component that is related with students' character.

Table1. Observation results on students' character on decimal subjects.

\begin{tabular}{cccccc}
\hline No & Student's Name & $1^{\text {st }}$ Meeting & $2^{\text {nd }}$ Meeting & $3^{\text {rd }}$ Meeting & $4^{\text {th }}$ Meeting \\
\hline 1 & NS & Good & Good & Good & Good \\
2 & SR & Good & Good & Good & Good \\
3 & SM & Moderate & Moderate & Moderate & Moderate \\
4 & NH & Good & Very Good & Very Good & Very Good \\
5 & MR & Good & Good & Good & Good \\
6 & ZN & Moderate & Very Good & Very Good & Very Good \\
7 & RR & Moderate & Moderate & Moderate & Moderate \\
8 & IM & Good & Very Good & Very Good & Very Good \\
9 & SA & Good & Good & Good & Very Good \\
\hline
\end{tabular}


According to the table, it is shown that student NS after four meeting has shown a 'Good' character. Based on observation results along student NS learning process is confident in uttering their opinion when asked by the teacher, but only when asked. Student NS when doing the LAS always discuss it with their group member, when doing individual projects student NS did it by themselves although they did rum into some problem in understanding the subjects and the concept of decimals number division, this led to student NS to often asked around their classmates. Student NS did not shown much interest about the subjects and never propose an idea or new way in completing a given assignment.

Student SR after four meeting possess a 'Good' character. Based on the observation it is shown that student SR is not confident in voicing their opinion, discussing with the group when doing a group assignment and done the individual assignment by themselves but did not shown much interest about the subject and never propose a new idea or method in completing a given assignment.

Student SM after four meeting possess a 'Moderate' character. Based on the observation it is shown that student SM is not confident in voicing their opinion in a group when doing a group assignment and very non active. Student SM is too passive in a group and quite reserved, they are quite inactive in giving an opinion/argument, most of the time they just accept the group conclusion. Student SM often copies their classmate's assignment when doing individual assignment and did not shown much interest about the subject and never propose a new idea or method in completing a given assignment.

Student NH on the first meeting shown a 'Good' character, then in the following meeting shown development into a 'Very Good' character. On the first meeting, Student NH was quite reserved but becoming more active in the following meetings. Student NH is confident in voicing their opinion in front of the class. In a group discussion when working on LAS always start independently and then discuss it with their group member, somewhat acting as a leader of the group. They takes up more action and searching for the answer by themselves and then confirmed it to their group member to be corrected. Making student $\mathrm{NH}$ a very reliable member of a group. In working on individual assignment, student $\mathrm{NH}$ could finish it by themselves but did not show much interest on the subjects and mostly just following the teacher or book instructions.

Student MR after four meeting possess a 'Good' character. Based on the observation it is shown that student MR is not confident in voicing their opinion, discussing with the group when doing a group assignment and done the individual assignment by themselves confidently but did not shown much interest about the subject and never propose a new idea or method in completing a given assignment.

Student ZN on the first meeting shown a 'Moderate' character and quite inactive, the student is able to complete but didn't fully understand the subjects. However, in the following meeting student ZN shown a 'Very Good' character. They look active and confident in voicing their opinion. The students put in effort in working on the LAS and discuss it with their group member. In doing an individual assignment, Student ZN could do it themselves and only asking things that they don't quite understand to the teacher. Student ZN did shows an interest on the subject proven by the different kinds of book the student possess compared to the teacher, but still uses the method taught by the teacher or from the book to complete an assignment.Student RR after four meeting shown a 'Moderate' character. During observation, it was shown that student RR does less discussion with the group, mostly just copying the result from other group member. In doing individual assignment, the students prefer to copy their friend assignment rather than doing it themselves. Student PR shown to have possess low 
capabilities level on the subject. During the learning process, the students seems to be more inactive than the others.

Students IM shows a 'Good' character on the first meeting, but on the following meetings shown a 'Very Good' character. During observation it is shown that the student is very active during learning process, Student IM was good in communicating with their teacher and classmates, always looking for a solution of a problem and discuss it with their group mates. The student is confident in voicing their opinion and handling different opinion from their classmates. In doing independent assignment, Student IM always tried to do it by themselves. The students showed interest on the subject, shown by the action of asking question to the teacher.Student SA on the first three meeting showed a 'Good' character and a 'Very Good' character on the last meeting. Based on the observation, it was shown that Student SA is active inside a group but faces difficulty when doing a story question and in understanding the concept of decimal number divisions, delaying the process considerably. However, in doing independent assignment, the student proves to be quite adept in completing the task. The students asked questions to the teacher quite a lot, but did not shown much interest on the subject or proposes new idea to solve the problem.

These are the result of the students characters score as a whole from the first meeting to the last meeting.

\section{Students' character}$$
222
$$
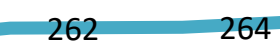

1st Meeting 2nd Meeting 3rd Meeting 4th Meeting

Gambar 1 Students' Character Development on Decimal Subjects

The following are observation results of students' character during the research.

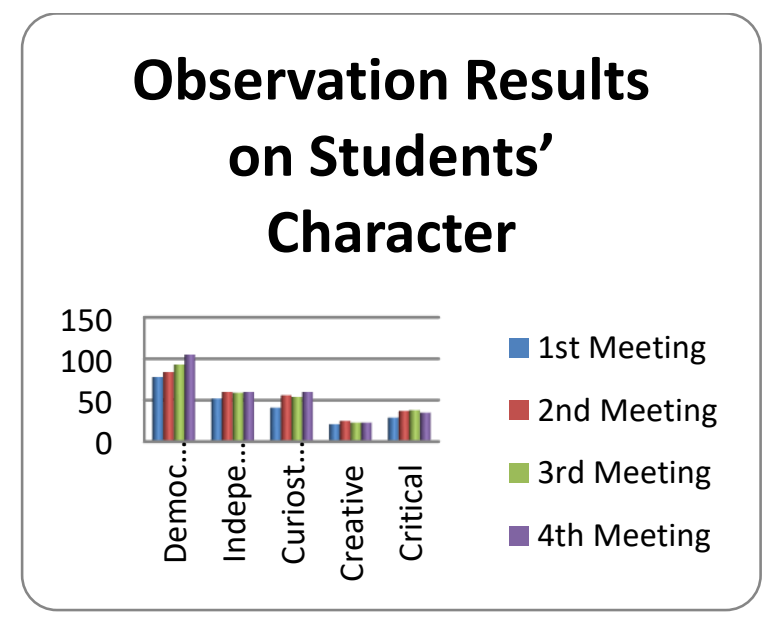

Gambar 2: Observation Results on Students' Character 
The following are the observation results of student's character on block subjects after three meeting.

Table 2: Observation Result of Students' character on block subjects.

\begin{tabular}{ccccc}
\hline No & Students' Name & $1^{\text {st }}$ Meeting & $2^{\text {nd }}$ Meeting & $3^{\text {rd }}$ Meeting \\
\hline 1 & NS & Moderate & Good & Good \\
2 & SR & Moderate & Good & Good \\
3 & SM & Moderate & Moderate & Moderate \\
4 & NH & Very Good & Very Good & Very Good \\
5 & MR & Good & Good & Good \\
6 & ZN & - & Good & Very Good \\
7 & RR & Moderate & Moderate & Moderate \\
8 & IM & - & Very Good & Very Good \\
9 & SA & Good & Good & Very Good \\
\hline
\end{tabular}

According to the table, on the first meeting two students could not attend the class because they need to take part in a school activity.

The followings are the overall students character score from the three meetings regarding block subjects.

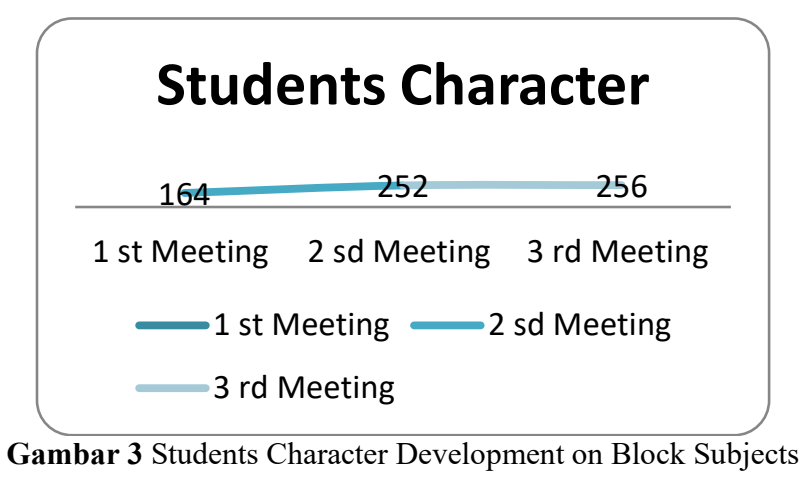

From the Gambar above it could be seen that the observed student's character was increasing. For democratic character, out of 9 observed students 6 (NH, IM, MR, SA, NS, and $\mathrm{ZN}$ ) is confident when voicing their opinion while the other 3 (SR, SM, RR) was not. The followings are snippet from the interview between the researchers and the sample done in order to collect supporting data on the observation of student's character.

The following are snippets form student SA interviews

$\mathrm{P} \quad$ : During the learning process, do you fell confidence in voicing your opinion?

(Selama proses pembelajaran, apakah kamu berani menyampaikan pendapat?)

SA : I am confident

(Berani)

$\mathrm{P} \quad$ : How did you voices your opinion?

(Bagaimana caranya kamu menyampaikan pendapat?)

SA : Usually by going to the front of the class, if the teachers asked a question, I raise my hand to volunteer and wait to be called upfront. If they don't call me, I don't go. I felt that was rude.

(Biasanya maju ke depan. Kalau guru bertanya, tunjuk tangan dulu kemudian tunggu disuruh sama guru, kalau tidak disuruh takutnya tidak sopan.)

$\mathrm{P} \quad$ : Why did you felt confidence in voicing your opinion> 
(Kenapa kamu berani menyampaikan pendapat?)

SA : Because the teacher asked, if not I would just be quiet.

(Karna sudah disuruh sama guru, kalau tidak disuruh diam saja.)

The following are snippets form student SM interviews

$\mathrm{P} \quad$ : During the learning process, do you fell confidence in voicing your opinion?

(Selama proses pembelajaran, apakah kamu berani menyampaikan pendapat?)

SM : No

(Tidak Berani)

$\mathrm{P} \quad$ : Why aren't you confident to voice your opinion?

(Kenapa kamu tidak berani menyampaikan pendapat?)

SM : Because I did not know the answer

(Karena tidak tahu jawabannya.)

$\mathrm{P} \quad$ : If the teacher asked another question, what would you do?

(Kalau guru memberikan pertanyaan kepada mu, apa yang kamu lakukan?)

SM: If I know the answer I would answer it, if not I would be quiet.

(Kalau saya tahu jawabannya saya jawab, kalau tidak tahu diam saja)

From the following it could be concluded that students SA and MR is confident to voice their opinion when asked by the teacher, while student SM is not confident because they did not know the answer to the question asked by the teacher.

For the independent character out of the observed 9 students $6(\mathrm{NH}, \mathrm{IM}, \mathrm{SA}, \mathrm{NS}, \mathrm{ZN}$, and $\mathrm{SR}$ ) could complete they assignment alone while the other 3 (MR, SM, and RR) copies their friend assignment.

The following are snippets from student $\mathrm{NH}$ interview

$\mathrm{P}$ : If you were given an assignment, do you usually finished it alone or copies a friend.?

(Jika ada tugas yang diberikan, biasanya menyelesaikannya sendiri atau meniru pekerjaan teman?)

$\mathrm{NH}:$ I did it by myself

(Kerjakan sendiri)

$\mathrm{P} \quad$ : How do you usually do it, what method do you uses in completing those assignment? (Biasanya dalam menyelesaikan tugas itu, bagaimana caranya? Apa saja yang dilakukan?)

$\mathrm{NH}$ : Well, just finding the solution, sometimes if my friend would come up to answer a question, I would do it by myself to see if I can do it or not.

(Mencari, misalnya ada kawan yang sedang maju, saya juga buat sendiri, biar saya tahu apakah saya bisa mengerjakannya apa tidak.)

$\mathrm{P}$ : Are you confident that you're able to complete the given task? (Apakah kamu yakin bahwa mampu menyelesaikan tugas yang diberikan?)

NH: I am. After I finished it I asked the teacher for confirmation if it's correct or not. (Yakin, bahwa saya pasti bisa menyelesaikannya. Setelah selesai saya bertanya lagi sama guru apa yang saya buat ini sudah benar atau belum.)

The following are snippets from student RR interview

$\mathrm{P} \quad$ : If you were given an assignment, do you usually finished it alone or copies a friend? (Jika ada tugas yang diberikan, biasanya menyelesaikannya sendiri atau meniru pekerjaan teman?)

RR : I usually copies (Melihat punya kawan)

$\mathrm{P} \quad$ : Why don't you just ask your friend for the solution? Rather than just copies the answer 
(Kenapa tidak bertanya sama kawan bagaimana caranya? Jangan lagsung melihat punya kawan.)

RR: Because I don't understand and don't know the answer

(Karena saya tidak mengerti, jadi saya tidak tahu jawabannya)

From the interviews snippets above, it could be concluded that Student NH is able to finish the given assignment by themselves and confident in their work, after completing it the students ask for confirmation from the teacher. On the other hand, student RR always copies a friend assignment, due to them not understanding the solution or knowing the answer of the assignment given.

For the character of curiosity, of the 9 students observed 3 (IM, SA and ZN) shows a lot more interest about the subject while the other 6 (NH, MR, NS, SR, SM and RR) did not.

The following are snippets from student $\mathrm{ZN}$ interview

$\mathrm{P} \quad$ : Did you have further interest about the subject that you learned?

(Apakah kamu punya rasa ketertarikan yang lebih dalam tentang materi yang diajarkan?)

$\mathrm{ZN}:$ Yes I am

(Tertarik.)

$\mathrm{P}$ : Other than what the teacher gave you, have you tried to learn from another source? (Apakah kamu pernah mencari sumber lain selain yang diberikan guru?)

$\mathrm{ZN}$ : Yes I have, I studied it at home, if I find difficulties I could ask my father about it (Pernah cari sumber lain, belajar lagi di rumah sendiri, kalau misalnya belum mengerti tanya lagi sama ayah.)

The following are snippets from student IM interview.

$\mathrm{P} \quad$ : Do you have any further interest about the taught subjects?

(Apakah kamu punya rasa ketertarikan yang lebih dalam tentang materi yang diajarkan?)

IM : I do, yesterday the teacher told us to find the block net, it looks easy but it is actually quite difficult, the teacher only gave one example then I ask the question 'is there more than one net?', then teacher answer that there is more.

(Ada, kemarin guru menyuruh kita semua mencari jaring-jaring balok, kalau cari jaringjaring balok itu sepertinya mudah sekali tapi sewaktu membuatnya sudah susah, kemarin sewaktu guru menjelaskan tentang jaring-jaring balok, guru cuma memberikan satu contoh, kemudian saya bertanya kepada guru 'apa jaring-jaring cuma satu?', guru menjawab 'jaring-jaring balok masih ada yang lain.)

$\mathrm{P}$ : Do you look for other source material regarding the subject other than what's already been explained? Or it's enough by what you got from the teacher? (Apakah kamu pernah mencari sumber lain tentang materi yang diajarkan selain penjelasan yang diberikan oleh guru? Atau cuma dapat penjelasan dari ibu saja itu sudah cukup?)

IM : I do, just looks for different kind of the books than the teacher uses. (Ada, cuma cari tambahan dari buku saja selain yang guru jelaskan.)

The following are snippets from student NS interview.

$\mathrm{P} \quad$ : Do you have any interest about the subject taught?

(Apakah kamu punya rasa ketertarikan yang lebih dalam tentang materi yang diajarkan?)

NS : No, I usually just listen to what the teacher said. (Tidak, saya biasanya hanya terima apa yang disampaikan oleh guru saja.) 
$\mathrm{P}$ : Do you ever have a different ide or solution than your friends or have your own way to solve the problem other than way describe in the book?

(Apakah kamu pernah punya ide/penyelesaian yang beda sama teman yang lain atau punya penyelesaian dengan cara sendiri yang tidak seperti cara di buku?)

NS : Never, I based it on the book

(Tidak pernah, biasanya saya gunakan cara yang di buku.)

From the interview snippets above it could be concluded that student $\mathrm{ZN}$ have a good curiosty about the subject that has been taught, show by how the student look for other source material on the subject and learn at home and asked the parents to help with their difficulties. Student IM also shown a character of curiosity. However, student NS did not shown any interest, they just accept the lesson as taught by the teacher.

For the character of creative and critical thinking, these interview snippets reprersents the student's characters.

These following are snippets from students IM interview

P : Have you ever had an idea or solution that was different than your other friends or the books?

(Apakah kamu pernah punya ide/penyelesaian yang beda sama teman yang lain atau punya penyelesaian dengan cara sendiri yang tidak seperti cara di buku?)

IM : I have, yesterday when discussing block net, I used the same kind of square as the teacher but with different kind of net, when I asked the teacher, they said it was the correct answer.

(Pernah, kemarin sewaktu mencari jaring-jaring padahal saya pakai kotak yang sama dengan guru, kemudian jaring-jaring saya beda sama yang dibuat guru di papan tulis. Kemudian saya bertanya kepada guru dan kata gurunya betul jaring-jaringnya.)

$\mathrm{P}$ : Say, in completing an assignment, do you ever gave a different kind of solution for a correct answer and gain the same result?

(Misalnya dalam menyelesaikan tugas, apakah kamu pernah memberikan solusi

Jjawaban dengan cara lain selain jawaban yang sudah dibuat dan jawabannya juga sama dengan cara yang pertama?)

IM : I have, yesterday the teacher told us to make a block and I made 2. The teacher said that one is enough

(Pernah, kemarin sewaktu guru menyuruh gambar balok dengan ukuran sendiri, saya buat

dua gambarnya tapi guru suruhnya satu saja.)

The following are snippets form student SR interview

P : Have you ever had an idea or solution that was different than your other friends or the books?

(Apakah kamu pernah punya ide/penyelesaian yang beda sama teman yang lain atau punya penyelesaian dengan cara sendiri yang tidak seperti cara di buku?)

SR : Never

(Tidak pernah.)

$\mathrm{P}$ : Say, in completing an assignment, do you ever gave a different kind of solution for a correct answer and gain the same result?

(Misalnya dalam menyelesaikan tugas, apakah kamu pernah memberikan solusi/jawaban dengan cara lain selain jawaban yang sudah dibuat dan jawabannya juga sama dengan cara yang pertama?)

SR : Never 
(Tidak pernah)

From the interview snippets above it could be concluded that student IM have had a different kind of idea and solution than that of their friend or the book while student SR done their task according to the taught solution and never comes up with different way.

\section{References}

[1] E. Setyaningsih, "Kepedulian Guru Dalam Menanamkan Karakter Peserta Didik," no. November, pp. 978-979, 2012.

[2] M. Amini, "PERAN PENGASUHAN GURU PADA PEMBENTUKAN KARAKTER ANAK SEJAK DINI," vol. 1, no. 2, pp. 1-10, 2015.

[3] S. Subarinah, "Pengintegrasian Pendidikan Karakter Dalam Pembelajaran Matematika SD Yang Bernuansa PAKEM Menggunakan Kopermatik ( Kotak Permainan Matematika Realistik ),” pp. 978-979, 2012.

[4] S. Amri and A. Jauhari, Implementasi Pendidikan Karakter dalam Pembelajaran. Jakarta: PT. Prestasi Pustakaraya, 2011.

[5] T. Lickona, Educating for Character, Bagaimana Sekolah Dapat Memberikan Pendidikan Rasa Hormat dan Tanggung Jawab. Jakarta: PT. Bumi Aksara, 2012.

[6] M. W. Berkowitz, Understanding Effective Character Education. University of Missouri, 2007.

[7] Zubaedi, Desain pendidikan karakter. Jakarta: Kencana Prenada Media Group, 2011.

[8] H. Gardner, Frames Of Mind (The Theory of Multiple intelligences). NewYork: Basicbooks, 1983.

[9] T. Y. E. Siswono, "IMPLEMENTASI TEORI TENTANG TINGKAT BERPIKIR KREATIF DALAM MATEMATIKA," pp. 24-27, 2006.

[10] O. Hamalik, Psikologi Belajar dan Mengajar. Bandung: Remaja Rosdakarya, 2008.

[11] M. Yaumi, Pembelajaran Berbasis Multiple intelligences. Jakarta: PT. Dian Rakyat, 2012. 